ISSN 2598-7933 (online); 2598-7941 (cetak)

Vol. 2 No. 2 (2019): 433-470, DOI: $10.22437 /$ ujh.2.2.433-470

Ulasan Tokoh dan Pemikiran Hukum

\title{
Rasionalisasi Hukum Alam oleh Hugo Grotius: Dari Humanisasi Menuju Sekularisasi
}

\author{
Aulia Rahmat \\ Universitas Islam Negeri Imam Bonjol \\ auliarahmat@uinib.ac.id
}

\begin{abstract}
Hugo Grotius is a figure who is recognized as a thinker from rational natural law. Grotius thought about law is interesting to review, because of their existence at the turn of the Middle Ages and the tendency to shift or change of thought and knowledge at that time. This article shows that the socio-historical background of Grotius was born and grew up influencing him as a humanist and secular legal figure. At first, the rationalization of law by Grotius was carried out by humanizing natural law, but at the next stage he cundocted secularization by limiting religious domination of state authority. This shift in thinking occurred during the Middle Ages, where reason was no longer intended to explain Divine reason but rather emphasized the ability of logical thinking in humans. In this way, the lawmaking authority is slowly shifted from God to human ratio. This article also shows that the rationalization of law by Grotius is urgent and relevant at this time, especially in the development of international humanitarian law, international treaty law, intellectual property law, alternative dispute resolution, and arbitration. For Indonesia, the legal idea from Grotius is also relevant in seeking the role of law that supports the development of the economic and tourism sector, which has recently become a priority.
\end{abstract}

Keywords: Grotius; natural law; Divine law; human ratio. 


\section{Abstrak}

Hugo Grotius merupakan tokoh yang dikenali sebagai pemikir dari kalangan hukum alam yang rasional. Pemikiran Grotius tentang hukum menarik untuk diulas, mengingat keberadaannya pada masa peralihan Abad Pertengahan dan kecenderungan pergeseran atau perubahan pemikiran dan pengetahuan pada masa itu. Artikel ini menunjukkan, latar belakang sosio-historis Grotius lahir dan besar turut memengaruhinya sebagai tokoh yang berhukum secara humanis sekaligus sekular. Apabila pada awalnya rasionalisasi hukum oleh Grotius dilakukan dengan melakukan humanisasi terhadap hukum alam, pada tahap berikutnya ia melakukan sekularisasi dengan mengadakan pembatasan dominasi agama terhadap otoritas kekuasaan negara. Pergeseran pemikiran ini terjadi pada masa peralihan Abad Pertengahan, di mana akal budi tidak lagi dimaksudkan untuk menjelaskan akal budi ilahiah melainkan lebih menekankan pada kemampuan berpikir logis manusia. Dengan begitu, otoritas pembuatan hukum perlahan digeser dari Tuhan kepada rasio manusia. Artikel ini juga menunjukkan, rasionalisasi hukum oleh Grotius urgen dan relevan pada saat ini terutama dalam pengembangan hukum humaniter internasional, hukum perjanjian internasional, hukum kekayaan intelektual, hukum perdamaian, alternatif penyelesaian sengketa, dan juga arbitrase. Bagi Indonesia, ide hukum dari Grotius juga relevan dalam mengupayakan peran hukum yang mendukung pengembangan sektor ekonomi dan pariwisata, yang belakangan ini menjadi prioritas.

Kata kunci: Grotius; hukum alam; hukum Tuhan; rasio manusia.

\section{A. Pendahuluan}

Artikel ini mengulas tokoh Hugo Grotius dan pemikirannya terkait dengan hukum alam. Dalam kajian filsafat hukum, Grotius dikenali sebagaipemikirdarikalanganhukumalamyangrasional.Pemikirannya tentang hukum menarik diulas, mengingat keberadaannya pada masa peralihan Abad Pertengahan dan kecenderungan pergeseran atau perubahan pengetahuan pada masa itu. Peran akal budi dan kemampuan berpikir logis yang semakin menonjol pada masa itu, memberi pengaruh pada model pengembangan hukum yang diusung Grotius sehingga lebih rasional, humanis, dan sekular. 
Dalam diskursus pemikiran hukum, Hugo Grotius dikenali sebagai salah satu tokoh yang berpengaruh pada perkembangan hukum dunia, terutama dalam konteks hukum internasional. Lahir dan besar dalam lingkungan keluarga bangsawan dan mempunyai intensitas dalam bidang hukum, Grotius memiliki bakat tersendiri dan cara pandang berbeda terhadap hukum. Pengaruh didikan orang tua dan model pendidikan interdisipliner yang ditempuh selama di Universitas Leiden mengantarkannya menjadi sosok yang berbeda. Akumulasi pengetahuan, pengalaman, serta konteks sosial historis yang berada di sekitarnya mengantarkan Grotius pada satu temuan menarik. Grotius menyatakan bahwa sumber utama dalam hukum adalah akal budi, bukan Tuhan. Pada kondisi ini, terma sekularisasi hukum alam dialamatkan kepadanya. Pemikiran Grotius tersebut dipengaruhi oleh latar belakang pendidikan pada masa kecil dan pengalaman terhadap kondisi sosial yang dialami pada masa pertarungan antara Belanda dengan Spanyol dan Perancis.

Banyak tokoh ${ }^{1}$ kemudian melakukan protes dan bantahan keras terhadap karya-karya Grotius. Meski demikian, juga tidak sedikit tokohyangterpengaruh olehnya. ${ }^{2}$ Kompleksitasinternaldan eksternal yang dialaminya mengantarkan Grotius pada dialektika keilmuan hukum yang bisa dikatakan logis dan mampu menyelesaikan ragam masalah yang muncul pada masa itu.

1 Di antara tokoh yang melakukan bantahan terhadap Grotius adalah Raja Charles I dari Inggris yang meminta kepada para ilmuwan di negaranya untuk membantah doktrin mare liberum. Pada 1625, Serafim de Freitas menerbitkan buku De Justro Imperio Lusitanorum Asiatico sebagai bantahan terhadap Grotius. John Selden adalah ilmuwan hukum terkemuka asal Inggris yang paling gigih melawan gagasan mare liberum. Pada 1636, sebagai reaksi terhadap ide Grotius, Selden menerbitkan Mare Claussum (Laut Tertutup), Atip Latipulhayat, "Grotius”, Padjadjaran Jurnal Ilmu Hukum, 4, 1 (2007), hlm. 211.

2 Tokoh yang disebut sangat terpengaruh oleh pemikiran Grotius adalah Gustavus Adolphus, Raja Swedia. Richard Tuck, "Introduction", dalam The Rights of War and Peace Book I, ed. Richard Tuck (Indianapolis: Liberty Fund, 2012), hlm. 68-69. Demikian juga dengan Pierre Bayle, Leibniz, Francis Hutcheson, Adam Smith, David Hume dan Thomas Reid (John Miller, "Hugo Grotius", Stanford Encyclopedia of Philosophy [Stanford University, 2014], hlm. 25). 
Dalam artikel ini, ulasan Grotius dan pemikirannya terkait hukum alam diawali dengan paparan riwayat hidup dan karyanya. Bagian ini dimaksudkan untuk mengenalkan latar belakang kehidupan dan pemikiran Sang Tokoh. Bagian berikutnya membahas pemikiran rasionalisasi hukum alam Grotius, yang dimaksudkan untuk menelaah latar belakang dan pekembangan rasionalisasi hukum alam oleh Grotius, yang ternyata menunjukkan pergeseran dari sebelumnya lebih menekankan soal humanisasi menuju pada sekularisasinya. Bagian berikutnya membahas urgensi dan relevansi pemikiran rasionalisasi hukum alam oleh Grotius.

\section{B. Riwayat Hidup dan Karya}

Hugeianus De Groot ${ }^{3}$ atau dalam bahasa latin dikenal sebagai Hugo Grotius, dilahirkan di Delft salah satu provinsi di Belanda pada tanggal 10 April $1583 .{ }^{4}$ Orang tuanya adalah John de Groote ${ }^{5}$ dan Alida Averschie. Ayahnya dikenal sebagai praktisi dan ilmuwan hukum terpandang pada masa itu. Nama Grotius, atau de Groot, merupakan

3 Beberapa literatur juga menulis Huig de Groot (Renèe Jeffery, Hugo Grotius in International Thought [New York: Palgrave Macmillan, 2006], hlm. 3). Dalam bahasa Belanda, nama Hugo Grotius dikenal juga dengan sebutan de Groot. Tuck, "Introduction", hlm. 60. Nama de Groot didapat dari nenek moyangnya, yang merupakan julukan atau persamaan dari kata The Great, mengingat jabatan hakim terpandang yang dimiliki oleh nenek moyangnya. Charles Butler, The Life of Hugo Grotius: With Brief Minutes of the Civil, Ecclesiastical, and Literary History of the Netherlands, Oxford University (London: Lincoln's-Inn Fields, 1828), hlm. 45.

4 Sebagian besar literatur menyatakan Grotius dilahirkan pada 1583. Martine Julia van Ittersum, Profit and Principle: Hugo Grotius, Natural Rights Theories and The Rise of Dutch Power in the East Indies (1595-1615), ed. A.J. Vanderjagt dkk. (Leiden: Brill, 2006), hlm. xxiv. Tuck, "Introduction”, hlm. 60. Namun juga ditemukan literatur yang menyebut ia dilahirkan pada 1852. Butler, The Life of Hugo Grotius, hlm. 42. Meski demikian, dengan memperhatikan isi surat-surat Grotius dengan paman dan saudaranya, diasumsikan ia dilahirkan pada 1583. M. de Burigny, Life of the Truly Eminent and Learned Hugo Grotius, ed. by GWF Hegel (London: Lord Bacon's Head, 1754), hlm. 3-6.

5 Butler, The Life of Hugo Grotius, hlm. 44. Pada literatur lain, penyebutan nama ayahnya adalah Jan de Groot. Van Ittersum, Profit and Principle, hlm. xxiv. 
warisan dari leluhurnya. Nenek moyangnya adalah Cornelius Cornets, seorang anggota Franche-Compte yang bermigrasi ke daerah Delft pada awal abad ke-15. Ketika berada di Delft, Cornelius Cornets berkenalan dengan hakim Diederick de Groot, dan menikahi anaknya, Ermengarda de Groot. Keluarga besar Hugo Grotius merupakan keturunan bangsawan.

HampirseluruhliteratursepakatmenyatakanGrotiusmerupakan seorang anak dengan kemampuan di atas rata-rata. Aspek keilmuan dan cara padangnya tidak terlepas dari didikan ayahnya. Sejak kecil ia sudah diperkenalkan dengan dasar-dasar ajaran Kristen. Grotius sangat tertarik dengan prinsip-prinsip dasar mengenai moralitas dan kemuliaan yang diajarkan oleh ibunya.

Pada 1594, sewaktu berusia 11 tahun, Grotius memulai pendidikannya di Universitas Leiden di bawah asuhan Francis Junius. Selama menempuh pendidikan, Grotius terkenal karena bakat, kecerdasan, dan kepatuhannya terhadap aturan-aturan yang berlaku. Berkat kecerdasannya Grotius kemudian dapat belajar dengan ilmuwanilmuwan terkenal saat itu, seperti Joseph Justus Scaliger dari Perancis, Justus Lipsuis dari Belanda, dan juga Simon Stevin. ${ }^{6}$ Selama berada di Universitas Leiden, Grotius meminati banyak cabang keilmuan yang ditawarkan, tidak hanya terbatas pada ilmu hukum saja. ${ }^{7}$ Tradisi pendidikan di Universitas Leiden mengantarkan Grotius menjadi sosok yang memiliki pengetahuan dan kompetensi dalam bidang sastra latin dan juga sejarah. Kompleksitas keilmuan dan pengetahuan yang dimilikinya ini mengantarkan Grotius menjadi sosok yang humanis. ${ }^{8}$

6 Charles Edwards, Hugo Grotius the Miracle of Holland: A Study in Political and Legal Thought (Chicago: Nelson-Hall, 1981), hlm. 5; R.W. Lee, Hugo Groitus: Annual Lecture on A Mastermind (London: Humphrey Milford, 2005), hlm. 2.

7 Tuck, "Introduction", hlm. xiii.

8 Robert Sommerville White, Natural Law in English Renaissance Literature (Cambridge: Cambridge University Press, 2006), hlm. 28. Marco Barducci, Hugo Grotius and the Century of Revolution 1613-1718: Transnational Reception in English Political Tought (New York: Oxford University Press, 2017), hlm. 5. Sisi humanis Grotius tidak dapat dilepaskan dari sosok Joseph Justus Scaliger yang menjadi penanggungjawabnya selama mempelajari seni 
Grotius menyelesaikan pendidikan di Universitas Leiden pada 1597. Setahun kemudian, Grotius mendapat kehormatan bergabung dengan Johan van Oldenbarnevelt ${ }^{9}$ dan Justin van Nassau dari Kedutaan Besar dalam sebuah misi diplomatik ke Kerajaan Perancis. Misi diplomatik yang dimaksud adalah berhubungan dengan Raja Henry IV dan mengusahakan agar Perancis tidak menjalin kerjasama dengan Spanyol. Hal ini dilakukan karena pada saat itu Belanda sedang dalam upaya memerdekakan diri dari penjajahan Spanyol. ${ }^{10}$

Raja Henry IV sangat terkesan dengan diskusi dan sikap Grotius, sehingga Grotius mendapatkan pelayanan yang ramah selama berada di Paris, dan juga diperkenalkan dengan beberapa tokoh berpengaruh di sana. Beberapa literatur menyebut keikutsertaan Grotius dalam misi tersebut hanya sebatas mendampingi Johan van Oldenbarnevelt. Misi tersebut tidak sepenuhnya berhasil seperti yang diharapkan. ${ }^{11}$ Meskipun demikian, akses pertemuannya dengan Raja Henry IV berimbas pada pemberian gelar kehormatan dengan sebutan "The Miracle of Holland”. Bahkan pada 1599, Grotius dianugerahi gelar Doktor dalam bidang ilmu hukum dari University of Orleans.

Setelah hampir setahun di Paris, Grotius kembali ke Belanda dan membuka kantor hukum dengan nama The Hague. Tidak jarang

liberal di Universitas Leiden. Lihat van Ittersum, Profit and Principle, hlm. xxiv.

9 Jon Miller, "Hugo Grotius", https://plato.stanford.edu/entries/grotius/, akses 12/10/2019. Johan van Oldenbarnevelt merupakan teman dekat Jan de Groot, ayah Grotius yang juga seorang advokat Belanda dan secara de facto merupakan pimpinan politik dari United Province. Kedekatan hubungan inilah yang kemudian diwarisi oleh Grotius dalam mendapatkan koneksi secara politis. van Ittersum, Profit and Principle, hlm. xxiv. Beberapa literatur klasik menyebut nama Johan van Oldenbarnevelt sebagai Barnevelt saja. Lihat Butler, The Life of Hugo Grotius, hlm. 46. Tuck, "Introduction", hlm. 60 .

10 Johan van Oldenbarnevelt dengan The United Province telah berusaha cukup lama mempertahankan kemerdekaan Belanda dari Spanyol (de Burigny, Life of the Truly Eminent, hlm. 10). Pada 1602, The United Province berupaya memperkuat posisinya terhadap dominasi Spanyol dengan memilih Grotius sebagai pimpinannya mengalahkan Dominicus Baudius (Jon Miller, "Hugo Grotius").

11 Latipulhayat, "Grotius”, hlm. 210. 
Grotius menyelesaikan kasus-kasus sipil pada Pengadilan Belanda. ${ }^{12}$ Tidak butuh waktu lama, perjalanan karir Grotius dan The Hauge meningkat dengan cepat. Di antara kliennya adalah Oldenbarnevelt, the Dutch East India Company (VOC), dan Pangeran Maurice dari Nassau. Pada saat membuka kantor hukum, Grotius tetap tidak meninggalkan dunia sastra liberal yang pernah dipelajarinya. Hal ini terlihat dari korespondensinya dengan Daniel Heinsius, Profesor Latin di Universitas Leiden, yang membantu Grotius dengan berbagai publikasi sastra. Pada 1601, Grotius menulis buku De Aquitante Raipublicae Batavicae (The Antiquity of The Batavian Republic) tentang legitimasi perjuangan Belanda untuk merdeka dari Spanyol. ${ }^{13}$ Tiga tahun kemudian, Grotius diminta untuk menulis risalah tentang pembelaan terhadap penangkapan Kapal Spanyol Santa Catarina di Selat Singapura pada 1603. Risalah tersebut diberi nama de Jure Preadea Commentarius, yang terdiri dari 11 bagian. Secara terpisah, bagian ke 12 diterbitkan tersendiri dengan judul Mare Liberium pada 1609.

Perjalanan karir Grotius ini semakin terbuka lebar ketika jabatan Advocate-General di Provinsi Belanda, Selandia dan Friesland Barat pada 1607 tidak ada yang mengisi. Pada masa ini Grotius menikah dengan Maria van Reigersbergh, putri Walikota Pelabuhan Veere. Pernikahan ini membawa pengaruh signifikan terhadap karir politiknya, hingga pada akhirnya Grotius menjabat sebagai penasihat hukum Kota Rotterdam dan menjadi anggota General Estates sebagai representasi dari provinsi asalnya. ${ }^{14}$

Pada musim panas 1618, Pangeran Maurice, yang saat itu menjabat Kepala Pasukan Angkatan Laut, merupakan pemerintah yang dikuasai oleh Calvinis Ortodoks. Grotius terlibat dalam upaya kudeta yang dikenal dengan tragedi remonstrans. Remonstrans pada dasarnya adalah gereja kecil yang mendapat dukungan penuh dari

12 Grotius menyelesaikan kasus hukum pertamanya pada usia 17 tahun. Hal ini yang membuat karirnya melonjak dengan tajam dan cepat. Butler, The Life of Hugo Grotius, hlm. 52.

13 Latipulhayat, "Grotius", hlm. 210.

14 Miller, "Hugo Grotius". 
Kuasa Perkebunan Belanda serta Oldenbarnevelt dan Grotius. Upaya Oldenbarnevelt dan Grotius berujung dengan kekalahan. Pangeran Maurice menangkap mereka berdua dan membuat mereka didakwa melakukan pengkhianatan. Grotius memberikan bukti terhadap teman lamanya dan dijatuhi hukuman penjara seumur hidup, sementara Oldenbarnevelt secara terbuka dipenggal pada Mei 1619. ${ }^{15}$

Selama berada dalam masa pengasingan, Grotius tetap produktif dalam menulis. Grotius mengedit Pengantar Yurisprudensi Belanda (Inleiding tot de Hollandsche Rechts-geleertheyd). De Jure Belli ac Pacis, yang merupakan karyanya paling fenomenal, ditulis selama dalam masa pengasingan, dan terbit di Paris pada 1625. Pada 22 Maret 1621, Grotius berhasil melarikan diri dari Kastil Loevestein melalui sebuah koper buku atas bantuan istrinya. ${ }^{16}$

Grotius kemudian memulai kehidupan barunya di Hamburg Jerman pasca mengalami penolakan dari tanah kelahirannya. Beberapa tahun kemudian, Grotius kembali ke Paris sebagai Duta Besar Kanselir Swedia, dengan tugas mengokohkan hubungan antara Katolik Prancis Katolik dan Protestan Swedia. Tugas Grotius sebagai duta besar Swedia tidak berhasil. Ia gagal memenangkan kepercayaan dari Cardinal de Richelieu, Perdana Menteri Louis XIII, yang ternyata sudah terlebih dahulu bernegosiasi dengan Oxenstierna. Pada 1645, Grotius akhirnya dipanggil kembali ke Stockholm. Ratu Christina menawari Grotius posisi sebagai anggota dewan kerajaan, namun ditolaknya. Hingga pada akhirnya Grotius memulai petualangan melintasi Laut Baltik, dan terdampar di Pelabuhan Rostock Jerman, dan meninggal dunia pada 28 Agustus $1645 .{ }^{17}$

Selama hidup, Grotius menulis banyakpublikasi, baikpadabidang sastra maupun bidang hukum. Karya perdana Grotius dipublikasikan pada 1601 dengan judul de Aquitante Raipublicae Batavicae. Buku ini diterbitkan ketika Grotius dipekerjakan sebagai ahli sejarah resmi Belanda. Buku ini, yang disusun berdasarkan permintaan Negara Bagian Belanda dan Friesland Barat, ditujukan untuk melegitimasi

15 Tuck, "Introduction", hlm. xv.

16 Tuck, "Introduction", hlm. xv.

17 Tuck, "Introduction", hlm. 62. 
pemberontakan Belanda terhadap pemerintahan Spanyol. Untuk karya ini, Grotius dibayar 300 pound. ${ }^{18}$ Buku ini merupakan propaganda pembenaran pemberontakan Belanda dengan alasan kedaulatan berada di tangan Belanda, seperti yang telah terjadi sejak zaman Batavia. Ide tersebut mempertanyakan legitimasi pendudukan Spanyol dan membuka jalan bagi Grotius untuk berpendapat bahwa Belanda sedang mengejar perang yang adil untuk mempertahankan kedaulatan integritas mereka.

Pada 1602, Grotius menulis de Jure Praedae Commentarius. Buku ini berisikan ulasan dan catatan Grotius terhadap legalisasi harta rampasan perang. ${ }^{19}$ Penulisan buku ini didasarkan pada keterlibatan Grotius sebagai praktisi hukum dalam menyelesaikan sengketa hukum antara Belanda dan Portugis terkait konflik perdagangan di daerah Selat Malaka. Buku ini tidak ditulis secara lengkap dan tidak pernah diterbitkan untuk beberapa alasan tertentu. Meskipun demikian, naskah buku ini ditemukan kembali pada 1864 dalam sebuah lelang internasional. Pada 1604 Grotius menulis buku de Indies, namun tidak banyak informasi yang ditemukan terkait buku ini.

Salah satu karya besar Grotius diterbitkan pada 1609 dengan judul Mare Liberum. Buku ini berisikan pemikiran Grotius terkait dengan argumentasi hak perdagangan VOC (Vereenigde Oost-Indische Compagnie/Dutch East India Company) yang terlibat dalam negosiasi gencatan senjata selama 10 tahun antara Belanda dan Spanyol. Pada saat itu, Belanda meminta pendapat Grotius terkait klaim Portugis terhadap wilayah laut di Samudera Hindia yang mengakibatkan kapalkapal VOC tidak dapat berlayar di sana. ${ }^{20}$ Beberapa ide utama buku ini

18 Jeffery, Hugo Grotius in International Thought, hlm. 5.

19 Benjamin Straumann, "Ancient Caesarian Lawyers in a State of Nature: Roman Tradition and Natural Rights in Hugo Grotius's De Iure Praedae", Political Theory, 34, 3 (2006), hlm. 332.

20 Uraian lebih mendalam terkait hal ini dapat disimak dalam Eric Wilson, "The Dangerous Classes: Hugo Grotius and Seventeenth-Century Piracy as A Primitive Anti-Systemic Movement", Journal of Philosophical Economics, 4, 1 (2010), 146-83. Martine Julia van Ittersum, "The Long Goodbye: Hugo Grotius' Justification of Dutch Expansion Overseas, 1615-1645”, History of European Ideas, 36, 4 (2010), 386-411. 
menyatakan konsep kepemilikan (possession), termasuk kepemilikan laut, hanya dapat terjadi terhadap benda-benda yang dapat dipegang teguh serta jelas batas-batasnya. Sementara laut adalah sesuatu yang tidak terbatas dan bersifat cair. Klaim kepemilikan terhadap laut sebagaimana lazim terjadi saat itu berdasarkan teori penemuan (discovery) atau penguasaan dalam jangka waktu lama (prescription) tidak dapat diterima.

Ide Grotius ini mematahkan dominasi Portugis terhadap penguasaan Samudera Hindia. Grotius menyatakan, dalam konsep lautan lepas, harus memperhatikan beberapa hal, yaitu hak kepemilikan, hak berlayar, dan hak berdagang. ${ }^{21}$ Eksistensi buku ini secara tidak langsung berpotensi menggoyang eksistensi Kerajaan Inggris sebagai pemegang otoritas pada masa itu. Doktrin Mare Liberum menuai protes keras dan dianggap membahayakan kekuatan status quo. Pada 1612, buku ini masuk dalam daftar buku terlarang yang dirilis oleh Lembaga Inkuisisi Spanyol. Raja Inggris, Charles I kemudian meminta kepada para ilmuwan di negaranya untuk membantah doktrin Mare Liberum. Pada 1625, Serafim de Freitas menerbitkan De Justro Imperio Lusitanorum Asiatico sebagai bantahan terhadap Grotius. John Selden adalah ilmuwan hukum terkemuka asal Inggris yang paling gigih melawan gagasan Mare Liberum. Pada 1636, sebagai reaksi terhadap ide Grotius, Selden menerbitkan Mare Claussum (Laut Tertutup). Buku ini menjustifikasi laut bisa dimiliki. Selden menyatakan, pengalaman sejarah membuktikan bahwa lautan dapat dimiliki oleh negara-negara yang memiliki kekuatan untuk menjaganya. Oleh karena itu, berdasarkan konsep prescription maka lautan dapat dimiliki. Argumen Grotius yang mengatakan laut tidak dapat dimiliki karena bersifat cair dibantah oleh Selden ${ }^{22}$ dengan menganalogikan laut terhadap sungai dan perairan pantai yang bersifat cair. Sungai dan daerah perairan pantai pada kenyataannya dapat dikuasai oleh negara-negara yang memiliki kekuatan untuk

21 David Armitage, "Introduction", dalam The Free Sea, ed. Hugo Grotius (Indianapolis: Liberty Fund, 2004), hlm. xv.

22 Meirav Jones, "Philo Judaeus and Hugo Grotius’s Modern Natural Law”, Journal of the History of Ideas, 74, 3 (2013), hlm. 340. 
menguasai dan menjaganya.

Pada 1611, Grotius menulis Meletuis Sive de iis Quae Inter Christianos Conveniunt Epsitola. Buku ini berisikan gagasan Grotius dalam pengembangan ide unifikasi umat Kristen pada masa itu. ${ }^{23}$ Penulisan buku ini dimotivasi oleh pengamatan Grotius yang menunjukkan kelestarian perang sejak masa nenek moyang tidak pernah tergoyahkan. Perang dimulai selain dengan dalih agama, yaitu perdamaian.

Grotius menulis Ordinum Hollandiae ac Westfriesiae Pietas pada 1613. Buku ini diterbitkan ketika Grotius berstatus sebagai seorang Advokat Fiskal Kerajaan Belanda. Penerbitan buku ini mengantarkannya pada kontroversi ide dengan jabatannya. Pada buku ini, Grotius mengedepankan aspek harmonisasi antar umat beragama. ${ }^{24}$ Grotius, karena posisinya, harus bertanggung jawab untuk negara terhadap tuduhan menjadi partisipan kriminal karena mengangkat Profesor secara luas di Universitas Leiden.

Sosok kontroversial Grotuis semakin dipertegas dengan publikasi De Imperio Summarum Potestatum Circa Sacra pada 1617. Ide utama buku ini menyatakan, summum imperium dapat dipegang oleh seorang individu atau sekelompok orang. ${ }^{25}$ Secara kritis, pemahaman yang diungkap oleh Grotius dalam buku tentang kemungkinan pemecahan kedaulatan. ${ }^{26}$ Grotius menyatakan, pemberontakan Belanda dapat dibenarkan dengan alasan pemberontakan tersebut diperjuangkan untuk membela tanda kedaulatan yang sah yang telah

23 Jeffery, Hugo Grotius in International Thought, hlm. 10. Lihat juga Henk Jan de Jonge, "Kajian Kritis-Historis terhadap Perjanjian Baru (de HistorischKritische Studie van Het Nieuwe Testament)", dalam Comparative History of Religion in Indonesia and the Netherlands (Leiden: INIS, 1992), hlm. 111-32. Ernestine van der Wall, "Between Grotius and Cocceius: The 'Theologia Prophetica' of Campegius Vitringa (1659-1722)", dalam Hugo Grotius, Theologian: Essays in Honour of G.H.M. Posthumus Meyjes, ed. Henk J.M. Nellen and Edwin Rabbie (Leiden: Brill, 1994), hlm. 195-215.

24 Jeffery, Hugo Grotius in International Thought, hlm. 28.

25 Silke-Petra Bergjan, 'The Patristic Context in Early Grotius', dalam Property, Piracy and Punishment: Hugo Grotius on War and Booty in de Iure Praedae Concepts and Contexts, ed. Hans W. Blom (Leiden: Brill, 2009), hlm. 128129.

26 Jeffery, Hugo Grotius in International Thought, hlm. 6. 
ditentang oleh perwakilan Spanyol di Belanda, Adipati Alva; yaitu, hak untuk menaikkan pajak.

Pada 1622, Grotius menulis Bewijs van den waren Godsdienst. Buku ini merupakan kumpulan puisi dan prosa yang ditulisnya. ${ }^{27}$ Pada awal 1620, Grotius menulis sebuah puisi yang awalnya hanya untuk diperlihatkan kepada teman-temannya. Versi awal naskah buku ini berjudul Geloofs Voorberecht. Karya ini dicetak secara diamdiam dan muncul pada Mei 1622 dengan judul Bewijs van den Waren Godsdienst. Edisi perdana buku ini terlepas dari teks yang ditulis oleh Grotius sendiri. Pada buku ini ditemukan sebuah puisi pendek yang ditulis oleh Willem de Groot, dan juga sebuah pengantar kontraremonstrant. Penambahan ini dilakukan tanpa sepengetahuan Grotius. ${ }^{28}$ Sebagai revisi terhadap buku ini, Grotius menerbitkan edisi kedua tanpa kata pengantar pada tahun yang sama. Grotius mendedikasikan karyanya untuk orang-orang Belanda, yang dia coba untuk meyakinkan cintanya dengan niat baik dari tanah airnya.

Karya monumental Grotius ditulis pada 1625 dengan judul De Jure Belli ac Pacis. Buku ini dikenal sebagai magnum opus seorang Grotius. Buku ini ditulis sejak 1622 dan selesai pada 1625. Ide penulisan buku didasarkan pengamatan Grotius terhadap kondisi sosial politik yang terjadi pada masa itu. ${ }^{29}$ Gejolak dan peperangan yang terjadi selama 30 tahun $^{30}$ memberikan dampak yang memprihatinkan. Gejolak peperangan yang terjadi disebabkan oleh klaim atas laut yang dilakukan oleh Paus Alexander XII pada 1493. Klaim atas laut ini

27 Karel Steenbrink, Kaum Kolonial Belanda dan Islam di Indonesia (1596-1942), terj. Suryan A. Jamrah (Yogyakarta: Gading, 2017), hlm. 64-67.

28 Jan-Paul Heering, Hugo Grotius as Apologist for the Christian Religion: A Study of His Work De Veritate Religionis Christianae (1649), terj. J.C. Grayson, ed. Robert J. Bast, dkk. (Leiden: Brill, 2004), hlm. 25-26.

29 Steven Forde, "Hugo Grotius on Ethics and War", The American Political Science Review, 92, 3 (1998), hlm. 639.

30 Yasuaki Onuma, Introduction to Normative Approach to War: Peace, War, and Justice in Hugo Grotius (Oxford: Clarendon Press, 1993), hlm. 8. Pada saat itu, konflik yang terjadi di Eropa adalah pertikaian antara negara-negara pantai terhadap klaim laut di luar Eropa yang dilakukan oleh Spanyol dan Portugis. Huala Adolf, "Sumbangan Hukum Alam dan Pemikiran Grotius terhadap Hukum Internasional”, Majalah Hukum Nasional, 2 (2017), hlm. 2 . 
dinyatakan secara tertulis dalam Piagam Inter Paetera. Isi piagam ini menyatakan bahwa seluruh laut dan samudera dibagi menjadi dua bagian saja, yaitu bagian milik Portugis dan bagian milik Spanyol. Buku ini dianggap melawan otoritas gereja yang berkuasa pada masa itu. Akibatnya, pada 1626 gereja menerbitkan larangan umat Gereja Katolik untuk membaca buku tersebut. Larangan ini baru dicabut pada 1899. Buku ini terdiri dari tiga: Buku I tentang konsepsi perang dan keadilan kodrati (perang dapat dibenarkan dalam beberapa kondisi); Buku II tentang tiga penyebab yang dapat dibenarkan untuk berperang (pertahanan diri, pemulihan kerugian, dan hukuman); dan Buku III tentang aturan-aturan pelaksanaan perang (semua pihak yang berperang terikat oleh aturan-aturan tersebut, terlepas dari apakah sebabnya dapat dibenarkan atau tidak).

Secara berturut-turut Grotius menulis De Veritate Religionis Christianae (1627), Inleiding tot de Hollandsche Rechtsgeleertheyd (1631), dan De Coena (1638). Buku-buku ini merupakan sebuah risalah diterbitkan secara rahasia di wilayah Amsterdam. Ide utama buku ini menyatakan, pada awalnya Gereja Kristen menawarkan sebuah cetak biru untuk komunitas agama yang dapat menerima semua orang Kristen. Pada 1638, Grotius menulis Semper Commincandum, yang pada dasarnya merupakan refleksi terhadap kondisi sosial masyarakat yang terjadi pada saat itu. Grotius menyatakan bahwa sekte-sekte keagamaan semakin berkembang, namun kualitas keimanan malah semakin menurun. Siapa pun yang berada di luar komunitas, tidak diterima di mana pun sebagai seorang anggota. Ia harus memikul keyakinannya dengan tenang sampai saat intoleransi telah berlalu.

Terakhir, pada 1641, Grotius menulis Annotata ad Consultationem Cassandri. Buku ini masih merupakan kritik dan refleksi terhadap kondisi sosial kemasyarakatan yang terjadi pada masa itu. Grotius menyampaikan argumennya bahwa tugas bersama yang harus dipikirkan adalah perdamaian. Salah satu cara yang ditawarkan adalah dengan mengurangi jarak dan konflik yang seringkali terjadi antara kaum Katolik Roma dengan golongan Reformis. 


\section{Rasionalisasi Hukum Alam oleh Grotius}

Guna melihat benang merah pemikiran dan kronologis perjalanan intelektual Hugo Grotius, dirasa perlu untuk meninjau dan membandingkan ide-ide yang ditulis dalam karyanya De Jure Belli ac Pacis dan De Jure Praedae Commentarius. Sebagian penggiat hukum menyatakan, De Jure Praedae Commentarius merupakan konsepsi awal dalam penyusunan De Jure Belli ac Pacis. Ditemukan beberapa perbedaan mendasar dalam pengembangan ide tersebut, sebagaimana uraian berikut.

\section{Struktur Formal Hukum dalam De Jure Praedea Commentarius}

Kerangka teoretis De Jure PraedeaCommentarius menjelaskan struktur pembedaan antara regulae (rules, aturan) dan leges (laws, hukum). Regulae (aturan) menetapkan beberapa sumber-sumber hukum. ${ }^{31}$ Setiap fungsi-fungsi regulae merupakan sebuah dasar untuk menyusun leges atau hukum, yang menurut Grotius diturunkan dari regulae.

Gambar 1. Struktur Formal de Jure Praedea

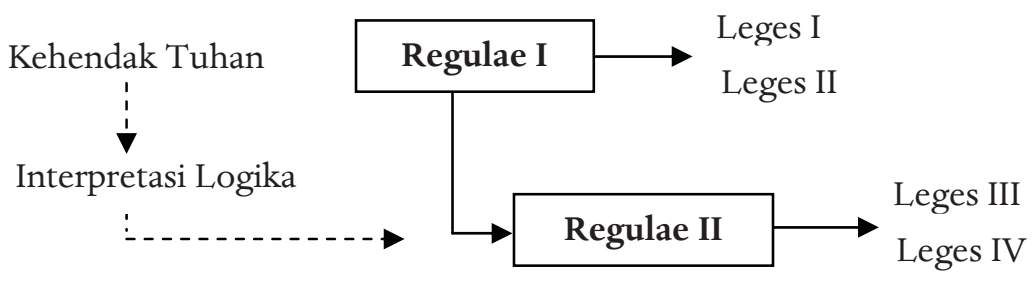

Pola dan konstruksi yang digunakan Grotius secara konsisten menunjukkan bahwa leges atau law selalu diturunkan dari regulae atau rule. Untuk memahami hubungan antara regulae dan leges yang berada di bawahnya, dibutuhkan sebuah regulae yang beroposisi sebagai penengah. Regulae II dibentuk dengan melakukan interpretasi terhadap regulae I. Leges I dan II yang memerintahkan kita untuk mempertahankan diri secara langsung berasal dari kehendak Tuhan,

31 Benedict Kingsbury, "A Grotian Tradition of Theory and Practice?: Grotius, Law, and Moral Skepticism in The Thought of Hedley Bull", QLR, 17, 3 (1997), hlm. 7. 
karena Tuhan menghendaki ciptaan-Nya untuk bertahan lama. Tetapi kemudian Grotius melanjutkan bahwa Tuhan tidak hanya menghendaki pelestarian kita sendiri, tetapi juga pelestarian seluruh spesies, sehingga menghendaki agar semua orang dapat terikat dalam keharmonisan timbal balik seperti perjanjian abadi. Keharmonisan ini merupakan dasar dari regulae II, yang menjadi dasar pembentukan leges III dan IV diturunkan.

Perdebatan yang menarik di sini adalah kedudukan dan urgensi regulae II sebagai penengah. Idealnya, jika memang leges III dan IV bertujuan untuk menjaga keharmonisan hubungan timbal balik guna pelestarian umat manusia, harusnya bisa langsung diturunkan dari kehendak Tuhan. Merujuk pada pola yang digunakan, Grotius terlihat ragu untuk mengaitkan secara langsung aturan-aturan sosial terhadap Tuhan, sehingga membangun dan memperkenalkan konsep kehendak bersama sebagai sumber tambahan untuk undang-undang yang mengatur umat manusia.

Pola dan argumen tersebut menyisakan persoalan baru ketika terjadi pertentangan antar aturan yang dibentuk dari dua sumber terdekat yang berbeda. Pertentangan tersebut berkaitan dengan skala prioritas. Terkait kemungkinan ini, Grotius menyatakan pada leges III bahwa pada kondisi di mana hukum dapat diamati secara bersamaan, biarkan mereka semua diamati, namun ketika ini tidak mungkin, hukum yang lebih tinggi akan berlaku. ${ }^{32}$ Struktur ini pada dasarnya mempunyai substansi sumber hukum yang berbeda, sehingga jika dikaji secara hierarkis akan ditemukan kesimpulan bahwa pemberian prioritas pada hukum-hukum yang menekankan pemeliharaan diri pada regulae I daripada perilaku sosial di regulae II. Ini berarti, dalam konflik kepentingan yang terjadi, maka kita harus memikirkan kepentingan kita sendiri terlebih dahulu.

Sebagai jalan tengah, Grotius menguatkan argumentasinya dengan menyatakan, meski hierarki tersebut telah mengindikasikan kebaikan seseorang lebih diutamakan daripada kebaikan orang lain, konsep yang lebih umum harus diutamakan, dengan alasan hal

32 Hugo Grotius, Commentary on The Law of Prize and Booty, ed. Matine Julia van Ittersum (Indianapolis: Liberty Fund, 2012), hlm. 500. 
itu termasuk kebaikan individu juga. Hal ini menunjukkan bahwa kebaikan individual merupakan bagian yang tidak terpisahkan dari kebaikan bersama.

Jika disimak secara seksama, pada dasarnya ide-ide tentang hukum yang abadi sebagaimana Aristotelian dan Aquinas masih terangkum jelas pada bagian Prolegomena, sebagai berikut:

Sejak Tuhan menciptakan makhluk dan menghendaki keberadaannya, setiap bagiannya telah menerima tanduk dengan sifat-sifat alami tertentu di mana keberadaannya dapat dilestarikan dan setiap bagian dapat dibimbing untuk kebaikannya sendiri, sesuai dengan hukum dasar yang melekat pada asalnya. Dari fakta ini, para penyair dan filsuf lama dengan tepat menyimpulkan bahwa cinta, yang kekuatan dan tindakan utamanya diarahkan pada kepentingan diri sendiri, adalah prinsip pertama dari keseluruhan tatanan alam. ${ }^{33}$

Grotius menulis secara eksplisit bahwa kodrat berfungsi sebagai pembimbing makhluk yang diciptakan demi kebaikan mereka sendiri. Artinya, alam dipahami sebagai tujuan. Perbedaannya dengan konsep Aristoteles dan Aquinas adalah, meskipun hukum abadi sebagai asumsi metafisik dihidupkan kembali, substansinya dibatasi. Menurut Grotius, desain Tuhan hanya mengungkapkan kecenderungan untuk mempertahankan diri. Kecenderungan untuk kehidupan sosial dan penekanan Aquinas pada keinginan untuk pengetahuan tentang Tuhan tidak dipakai lagi.

Keutamaan pemeliharaan diri sebagai satu-satunya kecenderungan yang benar-benar alami menjadi prioritas yang secara langsung didasarkan pada kehendak Tuhan. Jika seseorang membatasi kecenderungan yang Tuhan tanamkan di alam ke arah perlindungan diri saja, konsep hukum abadi Aristotelian dapat dengan mudah mengarah pada jenis skeptisisme yang dengannya semua moralitas didirikan dalam kebijaksanaan. ${ }^{34}$ Konteks ini menunjukkan bahwa pada awalnya Grotius tidak terlalu jauh dari skeptis yang mengklaim bahwa ibu dari segala keadilan adalah kebijaksanaan.

Grotius melakukan revisi signifikan terhadap De Jure Praedea

33 Grotius, Commentary on The Law of Prize and Booty, hlm. 16.

34 Pauline C. Westerman, The Disintegration of Natural Law Theory: Aquinas to Finnis, ed. A.J. Vanderjagt and others (Leiden: Brill, 1998), hlm. 137. 
pada De Jure Belli ac Pacis. Grotius mengkritik sikap skeptisisme ${ }^{35}$ dan pembatasan hukum ${ }^{36}$ abadi yang ditulisnya dalam De Jure Praedea. Grotius menyatakan bahwa kecenderungan untuk adil secara moral saja tidaklah cukup, akal harus turut serta dalam kecenderungan alami untuk mengubah nilai-nilai tersebut menjadi hukum. ${ }^{37}$ Eksistensi akal dalam pembentukan hukum menjadi distingsi utama antara manusia dan hewan. Hal ini juga menunjukkan bahwa hanya makhluk yang cerdas yang bisa tunduk kepada hukum.

Penekanan Grotius pada hubungan antara rasionalitas manusia dan hukum ini tidak serta merta mendorongnya menempatkan persetujuan bersama umat manusia sebagai sumber sejati bagi moralitas dan hukum. ${ }^{38}$ Konstruksi ide yang dibangunnya sendiri dalam De Jure Praedea disanggah sendiri oleh Grotius. Persetujuan bersama hanya dimungkinkan dalam peran epistemologis dalam pembenaran tindakan post hoc. Meskipun tidak menjadi jaminan mutlak, persetujuan bersama setidaknya menunjukkan eksistensi akal sehat manusia. Pergeseran ide utama Grotius ini disebabkan oleh perubahan dan dinamika peradaban yang disertai dengan kecenderungan berbuat salah dan distorsi mental masyarakat. ${ }^{39}$

\section{Kodrat Manusia}

Sebagian orang berpendapat bahwa ide-ide yang dikembangkan

35 Robert Shaver, "Grotius on Scepticism and Self-Interest", in Grotius, Purfendorf and Modern Natural Law, ed. Tom Campbell (Brookfield: Ashgate Publishing Company, 1999), hlm. 69. Simone Goyard-Fabre, "Hugo Grotius", The Philosophy of Law: An Encyclopedia of Routledge (Routledge, 2012), hlm. 335-37.

36 Dennis Patterson, A Companion to Philosophy of Law and Legal Theory: A Companion to Philosophy of Law and Legal Theory (Oxford dan Cambridge: Blackwell, edisi kedua, 1996), hlm. 86.

37 Hugo Grotius, The Rights of War and Peace, ed. by Richard Tuck and Jean Barbeyrac (Indianapolis: Liberty Fund, 2005), hlm. 72. Randy E. Barnett, "A Law Professor's Guide to Natural Law and Natural Rights", Harvard Journal of Law and Public Policy, 20, 3 (1997), hlm. 657.

38 Otto Gierke, Natural Law and the Theory of Society: 1500 to 1800, ed. Ernst Troeltsch and Ernest Barker (Cambridge: Cambridge University Press, 1934), hlm. 55.

39 Westerman, The Disintegration of Natural Law Theory, hlm. 139. 
Grotius dalam De Jure Praedea terbatas dalam konteks hukum positif saja. Grotius menilai, eksistensi kehendak Tuhan dan persetujuan bersama bukanlah sumber hukum yang komprehensif. ${ }^{40}$ Ia menyusun De Jure Balle ac Pacis dengan kerangka baru, dengan tujuan memberikan perbedaan sederhana antara hukum alam dan hukum positif. Hukum alam mengandung dasar-dasar yang disimpulkan dari alam, sedangkan hukum positif mengandung semua hukum yang bersumber dari kehendak berbagai otoritas, termasuk kehendak Tuhan.

Secara implisit, Grotius menyatakan sumber dari hukum alam adalah kodrat manusia. Ditemukan beberapa sifat yang berbeda yang ada dalam diri manusia, yaitu kecenderungan untuk mempertahankan diri, keinginan untuk masyarakat, pengetahuan, serta hak berpikir dan berbicara. ${ }^{41}$ Pada konteks ini, keramahan dan akal-budi memperoleh posisi yang dianggap berakar kuat di alam sebagai media pertahanan diri.

Ide utama yang diusung Grotius dalam De Jure Balle ac Pacis adalah hipotesis anti-theistik (etiamsi daremus). ${ }^{42}$ Secara lantang Grotius menyatakan, kita harus mengakui apa yang tidak dapat diakui tanpa kejahatan yang paling besar, bahwa tidak ada Tuhan, atau bahwa urusan manusia tidak menjadi urusan Tuhan. ${ }^{43}$ Menurut Grotius, satu-satunya hal yang penting adalah bahwa kodrat manusia merupakan sumber hukum alam. Kehendak Tuhan atau akal budi baru muncul jika ada pembahasan terkait asal usul sifat manusia. Apakah kodrat manusia adalah produk dari intelek Tuhan atau kehendak Tuhan tidak begitu penting untuk status hukum alam.

40 Mathew Levering, Biblical Natural Law: A Theocentric and Teleological Approach (London: Oxford University Press, 2008), hlm. 84.

41 Tuck, "Introduction", hlm. xiii.

42 M.B. Crowe, "The Impious Hypothesis: A Paradox in Hugo Grotius", dalam Grotius, Purfendorf and Modern Natural Law, ed. by Tom Campbell (Brookfield: Ashgate Publishing Company, 1999), hlm. 86. Michael Bertram Crowe, The Changing Profile of the Natural Law (Denhag: Martinus Nijhoff, 1977), hlm. 332. Lihat juga Jeremy Seth Geddert, Hugo Grotius and the Modern Theology of Freedom: Transcending Natural Right (New York: Taylor \& Francis, 2017), hlm. 3.

43 Grotius, Rights War Peace, hlm. 89. 
Hukum alam tidak secara langsung didasarkan pada Tuhan, tetapi hanya secara tidak langsung melalui kodrat manusia. ${ }^{44}$ Untuk mengubah hukum alam, Tuhan harus mengubah kodrat manusia terlebih dahulu. Karena tidak ada yang akan menyangkal kemungkinan Tuhan dapat mengubah sifat manusia sesuai keinginannya, kebebasan Tuhan tidak akan punah. Tetapi kebebasan untuk tidak mengubah hukum alam ${ }^{45}$ menjadi urusan Tuhan semata yang tidak dapat diakses oleh akal manusia.

Secara sederhana, hukum kodrat dicirikan ${ }^{46}$ sebagai hukum yang berasal dari kehendak Tuhan dengan menggunakan media moral sebagai filter dengan tujuan kelestarian seluruh alam semesta. Hukum kodrat merupakan sumber hukum tertinggi dalam membentuk aturan, karena berisikan ide-ide keadilan dan keberlanjutan semesta. Hukum kodrat bersifat universal sesuai dengan tuntutan akal budi manusia. Bentukan hukum kodrat merupakan sebuah struktur yang rasional.

\section{Hukum Tuhan (Divine Law)}

Kajian hipotesis anti-theistik (etiamsi daremus) menjadi perdebatan panjang di kalangan akademisi dan praktisi. ${ }^{47}$ Lebih lanjut, Grotius mengungkapkan sebagai berikut:

Sumber hukum lain selain sumber di alam, yaitu kehendak bebas Tuhan, yang dievaluasi luar semua akal sehat kita mengatakan kepada kita bahwa kita harus membuat kepatuhan. Tetapi hukum alam yang kita bicarakan, terdiri dari apa yang berhubungan dengan kehidupan sosial manusia dan

44 Knud Haakonssen, "Hugo Grotius and the History of Political Thought", dalam Grotius, Purfendorf and Modern Natural Law, ed. Tom Campbell (Brookfield: Ashgate Publishing Company, 1999), hlm. 36); A. Sony Keraf, Hukum Kodrat dan Teori Hak Milik Pribadi (Yogyakarta: Kanisius, 1997), hlm. 24.

45 Fransisco Jose Contreras, "Foreword", dalam The Treat of Natural Law: Unravelling a Philosophical Tradition, ed. Fransisco Jose Contreras (London: Springer, 2013), hlm. ix. Jonathan A. Jacobs, "The Reason of the Commandements: Rational Tradition Without Natural Law”, dalam Reason, Religion, and Natural Law: From Plato to Spinoza, ed. Jonathan A. Jacobs (Oxford: Oxford University Press, 2012), hlm. 108.

46 Keraf, Hukum Kodrat, hlm. 25-26.

47 Forde, "Hugo Grotius on Ethics and War", hlm. 640. 
apa yang disebut dalam pengertian yang lebih luas, yang berjalan seperti halnya dari sifat-sifat esensial yang ditanamkan dalam diri manusia, dapat dengan tepat dikaitkan kepada Tuhan, karena kehendak Tuhan bahwa sifat-sifat seperti itu ada dalam diri kita. ${ }^{48}$

Pernyataan ini menegaskan jika sifat manusia dijadikan sebagai titik tolak untuk menurunkan hukum alam, maka validitas derivasi tersebut tidak tergantung dari kepercayaan pada Tuhan. Hal ini tidak berarti bahwa Grotius tidak percaya pada Tuhan. Sebaliknya, ia percaya bahwa Tuhan adalah sumber utama dari sifat manusia. Sekularisasi Grotius terhadap hukum alam tidak menyingkirkan Tuhan dari tempat kejadian. ${ }^{49}$ Grotius hanya menambahkan, eksistensi kodrat manusia dalam rantai hubungan Tuhan dengan hukum. Penambahan kodrat manusia menjadi aspek pembeda utama antara hukum alam dan hukum Tuhan.

Grotius menyatakan, dalam hukum alam, peran Tuhan terbatas untuk menegaskan kembali kebenaran yang telah diciptakan pada saat penciptaan umat manusia. Sedangkan dalam hukum Tuhan, Tuhan dianggap memegang otoritas sebagai legislator utama. Hukum positif dan hukum alam berbeda secara logis. Oleh karena itu, sebagian ahli yang menyatakan Perjanjian Lama dapat digunakan sebagai sumber hukum alam, dikritik oleh Grotius. Menurut Grotius, sebagian besar aturan dalam Perjanjian Lama datang dari kehendak bebas Tuhan.

Terdapat dua aspek utama yang dapat digunakan sebagai indikator pembeda antara hukum Tuhan dan hukum alam. Pertama, hukum Tuhan senantiasa berupaya untuk menuju tingkat kesempurnaan moral yang lebih baik, sehingga dapat memuat dasardasar eksplisit tentang hal-hal yang diizinkan oleh hukum alam. Kedua, hukum alam hanya berisi dasar yang mengatur hubungan antar sesama manusia, sedangkan hukum Tuhan juga mengatur perilaku kita terhadap Tuhan. Perintah hukum alam diidentifikasi

48 Grotius, Rights War Peace, hlm. 90.

49 Westerman, The Disintegration of Natural Law Theory, hlm. 143. Lihat juga Knud Haakonssen, "Early Modern Natural Law Theories', dalam The Cambridge Companion to Natural Law Jurisprudence, ed. George Duke and Robert P. George (Cambridge: Cambridge University Press, 2017), hlm. 81 . 
dengan hukum positif. Perintah Tuhan secara eksplisit memang diperlukan untuk mengubahnya menjadi sebuah hukum yang mengikat. ${ }^{50}$ Konsep pembatasan Grotius terhadap hukum alam pada dasarnya menunjukkan hukum alam telah mengalami humanisasi dalam teori Grotius.

Grotius berupaya menyatukan beberapa ide menjadi sebuah konsep hukum alam yang koheren. Sifat manusia berfungsi sebagai dasar hukum alam. Pengesahan hukum alam dipahami dalam pengertian nalar manusia dengan mempertimbangkan kodrat manusia. Kodrat manusia menjadi perangkat multi-fungsi, yang menjadi penengah konsep ini. Pertama, jika hukum alam diberlakukan, maka konsep benar dan salah dapat ditemukan dengan membandingkan tindakan dengan sifat rasional. Jika tindakan sesuai dengan sifat rasional, tindakan itu baik secara moral, sebaliknya jika mereka tidak setuju dengan sifat rasional mereka dianggap salah. Untuk menentukan standar ukur yang dapat diandalkan, sifat manusia harus disajikan dalam bentuk ideal. Ciri-ciri esensial dalam sifat manusia harus dibedakan dari karakteristik ketidaksengajaan. Kedua, jika seseorang beranggapan bahwa pekerjaan akal terutama dalam membandingkan tindakan dengan alam, tentu dibutuhkan suatu standar yang tidak dapat diubah. Karakteristik diturunkan pada empat fitur utama dalam hukum alam, ${ }^{51}$ yaitu untuk menjauhkan kecenderungan penguasaan hak milik orang lain dan upaya mengembalikan milik orang lain dari apa pun yang mungkin dimiliki; untuk memenuhi janji; untuk memperbaiki kerugian yang terjadi karena kesalahan kita; dan untuk memberikan hukuman pada manusia sesuai dengan kesalahan mereka.

\section{Urgensi dan Relevansi}

Grotius mengembangkan teori hukum alam bukan untuk kepen-

50 Christine M. Korsgaard, The Sources of Normativity (Cambridge: Cambridge University Press, 1996), hlm. 7; 21-22; 28-30. Gary Bryner and Richard Vetterli, "Hugo Grotius and Natural Law: A Reinterpretation", The Political Science Reviewer, 22 (1993), hlm. 377.

51 Westerman, The Disintegration of Natural Law Theory, hlm. 150. 
tingannya sendiri. Profesinya sebagai pengacara ${ }^{52}$ mengharuskannya untuk menyelesaikan masalah-masalah hukum dengan pendekatan hukum alam, meskipun dia menggunakan sumber-sumber lain juga, seperti hukum Tuhan dan ajaran-ajaran klasik Kristen, terutama kaum Stoa. ${ }^{53}$ Ide utama Grotius diidentifikasi dari pernyataannya dalam paragraf 11 Prolegomena buku De Jure Belle ac Pacis yang menyatakan, etiamsi daermus non esse Deum ${ }^{54}$ (hukum kodrat akan tetap hidup meskipun Tuhan tidak ada).

Kodrat manusia sebenarnya tidak serta merta menjadi dasar hukum alam, tetapi sebagai dasar hak-hak alamiah. Hukum alam utama yang diturunkan oleh Grotius berasal dari kodrat manusia akan lebih masuk akal jika diposisikan sebagai formulasi hak, bukan hukum. Hal ini memungkinkan hubungan antara berbagai sifat esensial dari sifat manusia dengan lebih jelas. Begitu Grotius mulai menerapkan hukum alam menjadi hukum positif, hak untuk mempertahankan diri ternyata menjadi yang paling penting. Kecenderungan alami untuk bersosialisasi dan akal budi manusia dipandang sebagai instrumen untuk hak tersebut.

Terkait konsep pembatasan ruang lingkup hukum alam, Grotius memperluas ${ }^{55}$ ide Suârez. ${ }^{56}$ Westerman $^{57}$ telah melakukan

52 Richard Cumberland, A Treatise of the Laws of Nature, ed. Jon Parkin dan Knud Haakonssen (Indianapolis: Liberty Fund, 2005), hlm. ix. Pada dasarnya, Grotius tidak begitu disepakati sebagai seorang filsuf, beberapa penulis menyebutnya sebagai seorang epigone. Grotius selaku pencetus ide hukum alam rasional pada dasarnya hanya seorang cendekiawan yang humanis, praktisi hukum, dan politisi. Haakonssen, "Early Modern Natural Law Theories", hlm. 81.

53 Westerman, The Disintegration of Natural Law Theory, hlm. 157.

54 Hugo Grotius, The Rights of War and Peace, hlm. 1769. Uraian dan penjelasan lebih lanjut dapat disimak dalam David Novak, "Natural Law and Judaism", dalam Natural Law: A Jewish, Christian and Muslim Trialogue, ed. Anver M Emon, Matthew Levering, dan David Novak (Oxford: Oxford University Press, 2014), hlm. 14-15.

55 Jeremy Seth Geddert, "Beyond Strict Justice: Hugo Grotius on Punishment and Natural Right(s)", The Review of Politics, 76, 4 (2014), hlm. 559-588.

56 John Finnis, "Aquinas and Natural Law Jurisprudence", dalam The Cambridge Companion to Natural Law Jurisprudence, ed. George Duke and Robert P. George (Cambridge: Cambridge University Press, 2017), hlm. 28.

57 Westerman, The Disintegration of Natural Law Theory, hlm. 158-59. 
penyelidikan terhadap argumen-argumen Grotius. Pertama, ada banyak hal yang tidak diatur secara eksplisit oleh hukum alam, meskipun mereka diatur oleh hukum Tuhan. Hukum alam tidak mengandung peraturan tentang hal-hal tertentu, sehingga kekuatan kebijaksanaan umat manusia ditingkatkan. Kedua, lembaga-lembaga tertentu didirikan oleh kehendak bebas umat manusia. Meskipun hukum alam tidak menyinggung lembaga itu sendiri, ada beberapa ketentuan yang berlaku di dalam kerangka kerja institusi buatan manusia ini. Ketiga, materi hukum dapat diubah tanpa mempengaruhi validitas hukum itu sendiri. Teori Grotius menyajikan gambaran yang kompleks. Grotius beranggapan bahwa kriteria dan prinsip yang universal dan berlaku selamanya didasarkan pada alam. Namun harus ada pembatasan tegas antara makna alam dan sifat manusia. Hukum alam didasarkan pada keinginan manusia untuk mempertahankan diri yang dibenarkan berdasarkan persepsi rasional manusia.

Pergeseran paradigma Grotius terhadap sumber hukum alam menarik untuk dikaji lebih lanjut. ${ }^{58}$ Grotius menggunakan terma ius gentium ${ }^{59}$ (hukum bangsa-bangsa) dalam Male Liberum. Namun, terma ini tidaklah sama dengan apa yang dimaknai sebagai ius gentium pada masa sebelumnya. Ius gentium yang digunakan di sini diasosiasikan pada hukum bangsa-bangsa yang terlepas dari hukum alam. Grotius menekankan pembedaan antara hukum alam dan hukum bangsa-bangsa. Menurutnya, hukum bangsa-bangsa tidak lagi dianggap sebagai sub-bagian dari hukum alam, melainkan berdiri sendiri. ${ }^{60}$ Hukum bangsa-bangsa mempunyai kekuatan mengikat yang didasarkan pada kehendak negara-negara itu sendiri. Hukum

58 Perdebatan mengenai sekularisasi ini dapat diamati dalam beragam perspektif yang beragam, misalnya pendekatan teosentris atau teleosentris. Levering, Biblical Natural Law, hlm. 83. Lihat juga John D Haskell, "Hugo Grotius in the Contemporary Memory of International Law: Secularism, Liberalism, and the Politics of Restatement and Denial”, Emory International Law Review, 25, 1 (2012), hlm. 279-80.

59 Fahmi Ahmadi, Kupas Tuntas Pemikiran Filsuf Hugo Grotius (Indonesia: Youtube, 2019).

60 Carl Joachim Friedrich, The Philosophy of Law in Historical Perspective (Chicago: The University of Chicago Press, edisi kedua, 1963), hlm. 63-66. 
bangsa-bangsa ini tidak terkait dengan persoalan-persoalan yang di luar jangkauan seperti keadaan pikiran, namun hanya mengikat sikap luar dari negara-negara dan pemimpinnya.

Guna melihat proses secara lebih rinci, indikator yang bisa dijadikan tolok ukur utama adalah definisi hukum dalam pandangan Grotius. Dalam De Jure Praedae, Grotius menyatakan hukum merupakan sesuatu yang bersumber dari Tuhan sebagai pencipta alam semesta (divine will, lex divana). Sedangkan pada De Jure Belli ac Pacis, Grotius menyatakan hukum dan perintah akal budi luhur yang menunjukkan keharusan atau penyimpangan moral dalam beberapa hukum berdasarkan kecocokan atau tidak terhadap rasionalitas ilmiah. ${ }^{61}$ Pemahaman Grotius pada De Jure Belli ac Pacis menunjukkan bahwa pada dasarnya hukum alam menganut prinsip validitas intrinsik. Validitas intrinsik ini ditujukan untuk membangun tatanan moral yang bersifat universal dalam dialektika pertarungan internal paham Kristen pada masa itu. Sedikit atau banyak, hal ini mengindikasikan bahwa ide ini dipengaruhi oleh kondisi degradasi dogma Kristen ${ }^{62}$ di tengah masyarakat pada masa itu.

Menurut Grotius, pertanyaan utama bukan lagi apakah hukum positif itu sesuai dengan hukum alam atau tidak, tapi apakah masyarakat sudah sesuai dengan hukum alam dan kodrat manusia. Hal ini muncul karena Grotius tidak lagi memandang masyarakat sebagai sebuah asosiasi alami, melainkan asosiasi buatan yang menyerupai alami. Grotius menampilkan konsep yang jauh lebih terpadu. Kemasyarakatan dan akal budi tunduk pada tujuan besar pemeliharaan diri, ${ }^{63}$ sehingga orang dapat memahami pemeliharaan diri mereka hanya dijamin dengan hidup dalam masyarakat. Itulah

61 Jeffery, Hugo Grotius in International Thought, hlm. 36. Secara sederhana, ide Grotius ini menyatakan bahwa semua negara terikat dengan hukum alam, yang memisahkan antara Hukum Tuhan dan akal budi. F.X. Adji Samekto, "Menggugat Relasi Filsafat Positivisme dengan Ajaran Hukum Doktrinal", Jurnal Dinamika Hukum, 12, 1 (2012), hlm. 77.

62 Ian McLeod, Legal Theory, ed. Marise Cremona (London: MacMillan Press, 1999), hlm. 39. Lihat juga Haakonssen, “Early Modern Natural Law Theories", hlm. 90.

63 Hans W. Blom, "Sociability and Hugo Grotius", History of European Ideas, 41, 5 (2015), hlm. 591. 
sebabnya hukum alam, yang berasal dari kodrat manusia, hanya memperingatkan individu untuk menepati janjinya dan tetap berada dalam masyarakat. Pentingnya pelestarian diri dan penundukan sosialisasi dan alasan sebagai alat untuk tujuan itu menjelaskan mengapa sifat-sifat yang terakhir ini tidak dapat berfungsi sebagai dasar untuk ajaran alami yang menurutnya hukum positif dapat dievaluasi. ${ }^{64}$

Sekularisasi ${ }^{65}$ hukum alam yang dilakukan oleh Grotius tidak dapat dilepaskan dari reformasi di wilayah Eropa Utara dengan mengambil momen reformasi gereja yang dilakukan kaum Kristen Protestan. ${ }^{66}$ Grotius menolak dominasi teologi Katolik Roma dan paham hukum alam irasional kaum Thomis. Grotius memilih pada penguatan posisi akal budi sebagai sumber hukum alam sebagai bentuk perlawanan terhadap kelompok Calvinis Ortodoks. ${ }^{67} \mathrm{Hal}$ inilah yang kemudian menjadi dasar penyebutan model hukum alam yang dikembangkan Grotius merupakan aliran rasional. Grotius melakukan perluasan terhadap makna akal budi yang pernah diperkenalkan sebelumnya oleh Plato sebagai nalar sosial umat manusia (social nature of humankind). Menurut Grotius, akal budi tidak hanya sebatas kehendak untuk hidup bersama dalam masyarakat,

64 Forde, "Hugo Grotius on Ethics and War", hlm. 642.

65 Beberapa literatur yang ditemukan juga menggunakan terma liberalisasi. Liberalisasi dimaknai dengan pembatasan hubungan antara gereja dan negara. Terma ini tidak dapat dilepaskan dari derivasi terhadap pemaknaan konsep divine law dalam kajian era renaisans dengan menempatkan Thomas Hobbes sebagai tokoh utamanya. Lihat Chripstopher Wolfe, Natural Law Liberalism (Cambridge: Cambridge University Press, 2006), hlm. 131-37.

66 Latipulhayat, "Grotious", hlm. 212. Pada abad pertengahan, ikatanikatan keagamaan semakin menguat hingga mempengaruhi semua aspek kehidupan pada masa itu. Puncaknya adalah pada pemikiran Grotius dan Pufendorf. Lihat Samekto, "Menggugat Relasi Filsafat Positivisme", hlm. 77. Sekularisasi ini berdampak negatif terhadap posisi agama. Pengakuan teori hukum alam yang semula menempatkan agama sebagai dasar hukum mulai tersisihkan. Jawahir Thontowi, "Pengembangan Ilmu Hukum Berbasis Religiuos Science: Dekonstruksi Filsosofis Pemikiran Hukum Positivistik”, Pandecta: Research Law Journal, 6, 2 (2013), hlm. 204.

67 T.J. Hochstrasser, Natural Law Theories in the Early Enlightenment, ed. Quentin Skinner and others (Cambridge: Cambridge University Press, 2004), hlm. 4. Lihat juga Haakonssen, "Early Modern Natural Law Theories”, hlm. 99. 
namun juga kehendak untuk hidup dalam masyarakat yang damai dan tertib (peaceful and well-ordered society). Secara sederhana, Grotius menghendaki akal budi tidak hanya dijadikan syarat guna menjaga tertib sosial dalam masyarakat, namun lebih dari itu, merupakan sumber segala hukum. Premis-premis ini mengantarkannya pada sebuah kesimpulan bahwa hukum alam itu kekal dan tetap, serta tidak dapat diganti bahkan oleh Tuhan sekalipun.

Jika disimak ke belakang, pada saat Grotius dilahirkan, Belanda sedang melakukan pemberontakan untuk membebaskan diri dari Kerajaan Spanyol. Kuatnya serangan yang dilancarkan Belanda, didukung kekalahan Tentara Spanyol serta menguatnya kekuasaan Henry IV di Perancis, dinilai cukup mempengaruhi lingkungan kehidupan kecil Grotius. Pada awal abad ke-17, Belanda dihadapkan pada pemisahan negara bagian utara dan selatan. Wilayah bagian utara didominasi oleh kaum otoritarianisme Calvinis. ${ }^{68}$ Karena itu, secara tidak langsung Grotius mengalami dan terlibat dalam dinamika konflik tersebut. Selama menempuh pendidikan di Universitas Leiden, Grotius mempelajari ilmu-ilmu filsafat klasik, yang pada saat bersamaan pengaruh renaisans, humanisme dan ajaran Kristen semakin menguat. ${ }^{69}$ Tradisi sekularisme Universitas Leiden yang mengedepankan kebebasan intelektual dan beragama juga memberikan warna lain dalam perjalanan akademik Grotius.

Grotius dibesarkan dalam tradisi renaisans dan humanisme Kristen. ${ }^{70}$ Pola pikir Grotius dipengaruhi oleh Arminius, Episcopius,

68 Tuck, "Introduction", hlm. xiii.

69 Bryner dan Vetterli, "Hugo Grotius and Natural Law”, hlm. 375.

70 Henk Jan de Jonge, "Grotius's View of the Gospels and the Evangelists", dalam Hugo Grotious, Theologian: Essays in Honour of G.H.M. Posthumus Meyjes, ed. Henk J.M. Nellen dan Edwin Rabbie (Leiden, New York, dan Koln: Brill, 1994), hlm. 66. Bryner and Vetterli, "Hugo Grotius and Natural Law”, hlm. 381. Tuck, "Introduction”, hlm. xiii. Hans W Blom, "Grotius and Socinianism", dalam Socinianism and Arminianism, Antitrinitarians, Calvinist, and Cultural Exchange in Seventeenth Century Europe, ed. Martin Muslow and Jon Rohls (Leiden: Brill, 2005), hlm. 124. Pembahasan lebih lanjut dapat dilihat dalam Christian Thomasius, Ian Hunter, Thomas Ahnert, dan Frank Grunert, Essays on Church, State, and Politics, ed. Haakonssen (Indianapolis: Liberty Fund, 2007), hlm. 128. 
Limborch, Erasmus, More, Colet, Ficino, Petrarch, dan beberapa ahli Romawi lainnya. Demikian juga dengan rekan-rekan ${ }^{71}$ dan berapa ide yang berkembang pada saat itu turut membentuk konstruksi pemikiran, keagamaan, politik, dan juga hukum. Grotius dibesarkan dalam tatanan keluarga yang humanis. Sebagai penganut Kristen yang humanis, Grotius mempunyai daya tarik dan pengetahuan yang mendalam terhadap Alkitab dan juga filsafat Yunani. Kompleksitas pemahamannya terhadap Alkitab dan juga filsafat membuatnya menjadi sosok yang menjunjung tinggi nilai kemanusiaan yang dipahaminya sebagai sebuah entitas abadi. Humanisme Grotius mengantarkannya pada pertentangan terhadap ide-ide determinisme. Grotius meyakini bahwa kebebasan dalam memilih merupakan hadiah dari Tuhan. Secara garis besar, ide-ide Grotius ini senada dengan pendapat Arminius, Episcopius, Uytenbogaert, dan Oldenbarnevelt dalam menilai konflik politik-agama yang merupakan gabungan antara kebebasan berkehendak, kekuatan gereja calvinis ortodoks, dan kemerdekaan lokal Provinsi Belanda.

Kedekatan Grotius dengan beberapa tokoh politik mengantarkannya sebagai bagian dari Arminius, seperti halnya Oldenbarnevelt, Episcopius, dan Uytenbogaert. Grotius juga turut terlibat dalam penyusunan Remonstrant pada masa Episopiuc. ${ }^{72}$ Ide tersebut bertentangan dengan Calvinisme. Sementara pada saat itu Calvinisme merupakan sebuah otoritas gereja negara yang mapan. Akibatnya,

71 Charles Wilson menguraikan beberapa teman Grotius, di antaranya adalah Caspar van Baerle, seorang humanis dan profesor hebat di Universitas Amsterdam; Johan Blaue, pencetak terkenal yang menerbitkan banyak buku-bukunya; Isaac Casaubon, seorang humanis dan teolog Prancis yang terkenal; Thomas Erpenius, orientalis yang setia; Simon Stevin, ahli matematika hebat; Vossius, pemikir besar Belanda lain yang memiliki hubungan dekat dengan Inggris; Johannes Uytenbogaert, pernah menjadi Chaplain ke Prince Maurice dan lawan utama ambisi teokratis dari the Calvinis ekstrem; PC Hooft, seorang humanis, penyair, dan sejarawan; Joost van den Vondel, penyair dan dermawan terkemuka Belanda; Johan van Oldenbarnevelt, Grand Pensionary dan Advokat dan Seal Keeper dari Provinsi Holland, dan John Lothrop Motley, perdana menteri Protestan Eropa. Bryner and Vetterli, "Hugo Grotius and Natural Law", hlm. 37273.

72 van Ittersum, Profit and Principle, hlm. xix. 
segala yang bertentangan dengan Calvinis dianggap bernilai politis. Ide-ide Arminianisme sejalan dengan Republikanisme, meski dinilai tidak cocok oleh pemerintah pusat. Ide yang dimaksud adalah peningkatan otonomi pada daerah provinsi, yang menurut Calvinis berpotensi membahayakan stabilitas serikat negara. Pada dasarnya, ide ini ingin membebaskan daerah provinsi dari kontrol ekstrem Calvinisme ortodoks. Singkatnya, perjuangan ide tersebut berakhir dengan hukuman ${ }^{73}$ penjara seumur hidup yang harus diterima Grotius di Kastil Loevestein.

Pemikiran Grotius dengan konsep hukum alam rasional mempunyai relevansi nyata terhadap beberapa aspek hukum. Pada tatanan ini, ide hukum alam rasional ditempatkan sebagai norma utama yang melandasi pembentukan beberapa aturan teknis lainnya. Meskipun dianggap telah telah melakukan sekularisasi terhadap hukum alam, Grotius sebenarnya melakukannya dengan pertimbangan penting. Penempatan kodrat dan akal budi sebagai sumber hukum diduga merupakan upaya jalan tengah yang dipilih guna menjaga universalitas nilai-nilai dalam hukum alam itu sendiri. Artinya, pada konteks utamanya Grotius tidak beranggapan bahwa Tuhan telah mati. Hanya saya kemudian Grotius menyatakan ide hukum alam yang dibawanya tidak terkungkung oleh dominasi oleh otoritas kekuasaan negara oleh agama. Ide-ide yang diungkapkan diharapkan bisa lebih universal dan dapat diterapkan pada negara manapun, mengingat tidak satupun ajaran agama yang mengizinkan terjadinya perampasan hak-hak terhadap seseorang tanpa ada alasan yang jelas.

Pada tatanan kontemporer, ide-ide hukum alam Grotius mempunyai relevansi nyata pada konsep pengembangan hukum humaniter internasional, hukum perjanjian internasional, hukum diplomatik, alternatif penyelesaian sengketa (alternative dispute resolution), dan juga arbitrase. Ide yang dimunculkan Grotius pada dasarnya disesuaikan dengan kebutuhan dan kompleksitas zamannya pada saat itu. Beberapa risalah yang ditulis digunakan sebagai analisis dan

73 Tuck, "Introduction", hlm. 13. 
justifikasi terhadap kebutuhan-kebutuhan tertentu. Misalnya, motif kelahiran serta eksistensi Mare Liberum, pada awalnya dapat diduga adalah sebatas kebutuhan politik praktis semata. Kebutuhan yang dimaksud adalah untuk menyelesaikan konflik penangkapan Kapal Spanyol. Kehadiran karya dan ide ini ditujukan untuk mendobrak kemapanan Portugis dan Spanyol dalam penguasaan Samudera. Jika diperhatikan secara normatif, ide ini pada dasarnya sesuai dengan prinsip-prinsip umum, yang menunjukkan warna khas pemikiran hukum alam irasional sebelumnya yang dikembangkan Thomas von Aquinas. Konsep kepemilikan di lautan lepas yang dibentuk Grotius tidak dapat sepenuhnya diterapkan terhadap konteks hukum perdata internasional. Dibutuhkan beberapa perbaikan dan sintesis dengan teori-teori lainnya guna bisa dipakai saat ini.

Merujuk pada pertarungan antara Grotius dan Selden, terlihat bahwa baik teori Grotius maupun Selden tidak dapat diterapkan secara kaku, mandiri dan rigid. Hukum laut yang dikenal saat ini, seperti tercermin dalam United Nations Convention on the Law of the Sea (UNCLOS), menerima sebagian doktrin Mare Liberum dan menerima sebagian doktrin Mare Clausum. UNCLOS misalnya mengakui konsep kepemilikan atas laut (seperti laut wilayah atau territorial sea), tetapi pada saat yang sama juga mengakui adanya hak melintas secara damai (innocent passage) yang harus dihormati oleh negara-negara yang memiliki laut.

Konteks yang paling memungkinkan untuk melihat relevansi ide Grotius adalah pada aspek hukum humaniter internasional. Hukum humaniter internasional merupakan serangkaian aturan yang menegaskan konteks-konteks kebolehan berperang. Sebagian besar aturan yang ada pada hukum humaniter internasional tidak dapat dilepaskan dari pengaruh buku De Jure Belli ac Pacis. Sebagian besar ketentuan yang dimuat dalam Konvensi Denhaag dan Konvensi Jenewa mempunyai kemiripan dengan ide Grotius. Keberadaan kesepakatan di antara beberapa negara dengan latar belakang dan model pemerintahan yang berbeda harus mempunyai kesamaan keinginan untuk membentuk aturan ini. Meskipun demikian, ditemukan juga beberapa hal yang sebelumnya tidak pernah dibahas 


\section{Aulia Rahmat}

oleh Grotius, seperti posisi Palang Merah pada saat terjadinya perang. Demikian juga halnya dengan eksistensi jenis kelamin ${ }^{74}$ serta keikutsertaannya dalam perang.

Ide-ide Grotius juga terlihat dominan dalam penyusunan pengembangan model hukum kontrak. Hal ini terlihat dalam Pasal 38 ayat (1) Statuta Mahkamah Internasional yang menyatakan Konvensi Internasional, baik secara umum ataupun sebagian, merupakan aturan yang mengatur secara tegas dan harus dipatuhi oleh negaranegara peserta. Pasal ini dapat dimaknai sebagai sebuah kesepakatan bersama untuk mengikatkan diripada perjanjian. Meskipun demikian, isi dari perjanjian-perjanjian tersebut diisyaratkan memuat nilai-nilai yang seimbang. Hal ini perlu mendapat perhatian lebih pada konteks Keindonesiaan, mengingat saat ini fokus pembangunan pemerintah adalah pengembangan aspek ekonomi dan pembukaan peluang investasi asing. Dasar-dasar ide hukum alam dirasa memberikan dasar ideal terhadap pengembangan regulasi yang berhubungan dengan dunia investasi dan ekonomi kreatif. Tidak kalah pentingnya juga adalah regulasi yang berhubungan dengan izin penambangan di wilayah Indonesia. Dibutuhkan pengkajian hukum yang mendalam dan komprehensif guna mencapai tujuan negara Indonesia.

Aspek lain yang juga tidak dapat dilepaskan dari konteks kajian hukum alam adalah perlindungan hak kekayaan intelektual. ${ }^{75}$ Ide hukum alam yang dikembangkan oleh Grotius merupakan tatanan ideal dalam pembentukan aturan-aturan teknis hak kekayaan intelektual. Kekayaan intelektual merupakan hak penuh dari penciptanya. Oleh sebab itu, maka perlindungan terhadap ciptaan dan hak yang ditimbulkannya merupakan sebuah keniscayaan. Seseorang yang telah menciptakan suatu ciptaan, harus mempunyai hak akses penuh untuk melakukan pengawasan dan pemilikan atas hanya tersebut. Eksistensi hukum alam pada konteks ini adalah sebagai penjaga moral

74 Pembahasan lebih lanjut baca: Helen M. Kinsella, "Gendering Grotius: Sex and Sex Difference on Laws of War", Political Theory, 34, 2 (2006), hlm. 161.

75 Khoirur Rizal Lutfi, “Teori Hukum Alam dan Kepatuhan Negara terhadap Hukum Internasional”, Jurnal Yuridis, 1, 1 (2014), hlm. 98. 
terhadap upaya pengabaian terhadap hak-hak tersebut. ${ }^{76}$ Sehingga, sebuah tindakan yang menyalahi hak-hak kekayaan intelektual tidak dapat dibenarkan.

Hukum alternatif penyelesaian sengketa, atau lazim dikenal sebagai non-penal atau non-litigasi juga dikembangkan dari konsep hukum perdamaian Grotius pada de Jure Balle ac Pacis. Hal ini tertuang secara jelas dalam ketentuan pasal 1 Piagam Perdamaian PBB tentang tujuan pembentukan PBB. Ada beberapa model alternatif penyelesaian sengketa yang dikenal umum. Pada konteks ini, Grotius lebih menekankan pada model arbitrase. Arbitrase merupakan upaya penyelesaian sengketa dengan menunjuk satu pihak independen sebagai penengah. Kesepakatan yang didapatkan dalam arbitrase bersifat final dan mengikat pada kedua belah karena diyakini memberikan solusi yang saling menguntungkan bagi kedua pihak.

\section{E. Kesimpulan}

Artikel ini menyimpulkan, pertama, pemikiran hukum Hugo Grotius yang mencoba merasionalisasi hukum alam tidak lepas dari latar belakang sosial-historis di mana ia lahir dan dibesarkan. Situasi pemberontakan di wilayah Belanda, tradisi renaisans dan humanisme Kristen, juga sekularisme di Universitas Leiden, menjadikan Grotius sebagai sosok yang berhukum secara humanis sekaligus sekular. Kedua, rasionalisasi hukum alam oleh Grotius sesungguhnya mengalami pergeseran. Hukum alam yang pada masa sebelumnya, sebagaimana diusung St. Agustinus dan St. Thomas Aquinas, lebih terlihat irasional, dicoba dirasionalisasi oleh Grotius dengan menambahkan akal budi dan logika sebagai medium penengah antara hukum alam dan hukum positif dalam struktur hukum yang disusunnya. Namun demikian, dalam perkembangan berikutnya hukum Tuhan disebutnya harus dipisahkan dari hukum positif manusia, dengan indikator yang bisa dijadikan tolok ukur penyimpangan adalah rasio akal budi yang dimiliki manusia. Hal

76 Fernando R. Teson, Liberty Matters: Hugo Grotius on War and the State (Indianapolis: Liberty Fund, 2014), hlm. 9. 
ini menunjukkan, jika pada awalnya Grotius melakukan humanisasi terhadap hukum alam, pada tahap berikutnya melakukan sekularisasi dengan mengadakan pembatasan dominasi agama terhadap otoritas kekuasaan negara. Apabila dicermati ide Grotius ini berada pada masa peralihan Abad Pertengahan, maka akan dipahami akal budi dalam terma ini tidak lagi dimaksudnya untuk menjelaskan akal budi ilahiah, namun lebih menekankan pada kemampuan berpikir logis, sehingga otoritas pembuatan hukum perlahan digeser dari Tuhan kepada rasio manusia. Ketiga, ide-ide Grotius tentang hukum dipandang urgen dan relevan hingga saat ini terutama dalam pengembangan hukum humaniter internasional, hukum perjanjian internasional, hukum kekayaan intelektual, hukum perdamaian, alternatif penyelesaian sengketa, dan juga arbitrase. Untuk konteks Keindonesiaan, ia juga relevan dalam mendorong hukum yang mendukung pengembangan sektor ekonomi dan pariwisata, yang belakangan ini menjadi prioritas pemerintah.

\section{Daftar Pustaka}

\section{Artikel/Buku/Laporan}

Adolf, Huala. "Sumbangan Hukum Alam dan Pemikiran Grotius terhadap Hukum Internasional”. Majalah Hukum Nasional, 2 (2017), 1-21.

Ahmadi, Fahmi. "Kupas Tuntas Pemikiran Filsuf Hugo Grotius", Youtube, 2019.

Armitage, David. "Introduction". Dalam The Free Sea, diedit oleh Hugo Grotius, i-xxxix. Indianapolis: Liberty Fund, 2004.

Barducci, Marco. Hugo Grotius and the Century of Revolution 1613-1718:

Transnational Reception in English Political Tought. New York:

Oxford University Press, 2017.

Barnett, Randy E. "A Law Professor's Guide to Natural Law and

Natural Rights". Harvard Journal of Law and Public Policy, 20, 3 (1997): 655-87.

Bergjan, Silke-Petra. "The Patristic Context in Early Grotius”. Dalam

Property, Piracy and Punishment: Hugo Grotius on War and Booty in 
de Iure Praedae - Concepts and Contexts, diedit oleh Hans W. Blom, 127-46. Leiden: Brill, 2009. DOI: 10.1163/ej.9789004175136.i422.

Blom,HansW. "SociabilityandHugoGrotius". Historyof EuropeanIdeas, 41, 5 (2015): 589-604. DOI: 10.1080/01916599.2014.987558.

Blom, Hans W. "Grotius and Socinianism". Dalam Socinianism and Arminianism, Antitrinitarians, Calvinist, and Cultural Exchange in Seventeenth Century Europe, diedit oleh Martin Muslow dan Jon Rohls, 121-47. Leiden: Brill, 2005.

Bryner, Gary, dan Richard Vetterli. "Hugo Grotius and Natural Law:

A Reinterpretation”. The Political Science Reviewer, 22 (1993): 370-402.

Burigny, M. de. Life of the Truly Eminent and Learned Hugo Grotius, diedit oleh GWF Hegel. London: Lord Bacon's Head, 1754.

Butler, Charles. The Life of Hugo Grotius: With Brief Minutes of the Civil, Ecclesiastical, and Literary History of the Netherlands. London: Lincoln's-Inn Fields, 1828.

Contreras, Fransisco Jose. "Foreword". Dalam The Treat of Natural Law: Unravelling a Philosophical Tradition, diedit oleh Fransisco Jose Contreras, i-xxi. London: Springer, 2013. DOI: 10.1017/ CBO9781107415324.004.

Crowe, M.B. "The Impious Hypothesis: A Paradox in Hugo Grotius". Dalam Grotius, Purfendorf and Modern Natural Law, diedit oleh Tom Campbell, 3-34. Brookfield: Ashgate Publishing Company, 1999.

Crowe, Michael Bertram. The Changing Profile of the Natural Law. Denhag: Martinus Nijhoff, 1977. DOI: 10.1007/978-94-0150913-8.

Cumberland, Richard. A Treatise of the Laws of Nature, diedit oleh Jon Parkin and Knud Haakonssen. Indianapolis: Liberty Fund, 2005.

Edwards, Charles. Hugo Grotius the Miracle of Holland: A Study in Political and Legal Thought. Chicago: Nelson-Hall, 1981.

Finnis, John. "Aquinas and Natural Law Jurisprudence". Dalam The Cambridge Companion to Natural Law Jurisprudence, diedit 
oleh George Duke dan Robert P. George, 17-48. Cambridge: Cambridge University Press, 2017.

Forde, Steven. "Hugo Grotius on Ethics and War". The American Political Science Review, 92, 3 (1998): 639-48. DOI: 10.4324/9781315093376.

Friedrich, Carl Joachim. The Philosophy of Law in Historical Perspective.

Chicago: The University of Chicago Press, edisi kedua, 1963.

Geddert, Jeremy Seth. "Beyond Strict Justice: Hugo Grotius on Punishment and Natural Right(s)". The Review of Politics, 76, 4 (2014): 559-588. DOI: $10.1017 /$ S0034670514000576.

Geddert, Jeremy Seth. Hugo Grotius and the Modern Theology of Freedom: Transcending Natural Right, e-Book. New York: Taylor \& Francis, 2017.

Gierke, Otto. Natural Law and the Theory of Society: 1500 to 1800, diedit oleh Ernst Troeltsch and Ernest Barker. Cambridge: Cambridge University Press, 1934.

Goyard-Fabre, Simone. "Hugo Grotius". Dalam The Philosophy of Law: An Encyclopedia of Routledge, 335-37. Routledge, 2012.

Grotius, Hugo. Commentary on the Law of Prize and Booty, diedit oleh Matine Julia van Ittersum. Indianapolis: Liberty Fund, 2012. Grotius, Hugo. The Rights of War and Peace, diedit oleh Richard Richard Tuck and Jean Barbeyrac. Indianapolis: Liberty Fund, 2005.

Haakonssen, Knud. "Early Modern Natural Law Theories". Dalam The Cambridge Companion to Natural Law Jurisprudence, diedit oleh George Duke dan Robert P. George, 77-102. Cambridge: Cambridge University Press, 2017. DOI: $10.1017 / 9781316341544$.

Haakonssen, Knud. "Hugo Grotius and the History of Political Thought”. Dalam Grotius, Purfendorf and Modern Natural Law, diedit oleh Tom Campbell, 35-62. Brookfield: Ashgate Publishing Company, 1999.

Haskell, John D. "Hugo Grotius in the Contemporary Memory of International Law: Secularism, Liberalism, and the Politics of Restatement and Denial”. Emory International Law Review, 25, 1 
(2012): 268-98.

Heering, Jan-Paul. Hugo Grotius as Apologist for the Christian Religion: A Study of His Work De Veritate Religionis Christianae (1649). Terjemah oleh J.C. Grayson, diedit oleh Robert J. Bast, dkk. Leiden: Brill, 2004.

Hochstrasser, T.J. Natural Law Theories in the Early Enlightenment, diedit oleh Quentin Skinner, Lorraine Daston, Dorothy Ross, dan James Tully. Cambridge: Cambridge University Press, 2004. Ittersum, Martine Julia van. Profit and Principle: Hugo Grotius, Natural Rights Theories and the Rise of Dutch Power in the East Indies (15951615), diedit oleh A.J. Vanderjagt, dkk. Leiden: Brill, 2006.

Ittersum, Martine Julia van. "The Long Goodbye: Hugo Grotius Justification of Dutch Expansion Overseas, 1615-1645”. History of European Ideas, 36, 4 (2010): 386-411. DOI: 10.1016/j. histeuroideas.2010.05.003.

Jacobs, Jonathan A. "The Reason of the Commandements: Rational Tradition Without Natural Law”. Dalam Reason, Religion, and Natural Law: From Plato to Spinoza, diedit oleh Jonathan A. Jacobs, 106-32. Oxford: Oxford University Press, 2012. DOI: $10.1017 /$ CBO9781107415324.004.

Jonge, Henk Jan de. "Grotius's View of the Gospels and the Evangelists”. Dalam Hugo Grotious, Theologian: Essays in Honour of G.H.M. Posthumus Meyjes, diedit oleh Henk J.M. Nellen dan Edwin Rabbie, 65-74. Leiden, New York, dan Koln: Brill, 1994. Jonge, Henk Jan de. "Kajian Kritis-Historis terhadap Perjanjian Baru (de Historisch-Kritische Studie van Het Nieuwe Testament)". Dalam Comparative History of Religion in Indonesia and the Netherlands, diedit oleh Burhanuddin Daya and H.L. Beck, 11132. Leiden: INIS, 1992.

Jeffery, Renèe.Hugo Grotius inInternationalThought. New York: Palgrave Macmillan, 2006. DOI: 10.1017/CBO9781107415324.004.

Jones, Meirav. "Philo Judaeus and Hugo Grotius's Modern Natural Law". Journal of the History of Ideas, 74, 3 (2013): 339-59. DOI: 10.1353/jhi.2013.0025.

Keraf, A. Sony. Hukum Kodrat dan Teori Hak Milik Pribadi. Yogyakarta: 
Kanisius, 1997.

Kingsbury, Benedict. "A Grotian Tradition of Theory and Practice?:

Grotius, Law, and Moral Skepticism in The Thought of Hedley Bull”. QLR, 17, 3 (1997): 3-34.

Kinsella, Helen M. "Gendering Grotius: Sex and Sex Difference on

Laws of War". Political Theoryry, 34, 2 (2006): 161-92.

Korsgaard, Christine M. The Sources of Normativity. Cambridge:

Cambridge University Press, 1996.

Latipulhayat, Atip. "Grotius". Padjadjaran Jurnal Ilmu Hukum, 4, 1

(2007): 209-21. DOI: 10.22304 / pjih.v4n1.a12.

Lee, R.W. Hugo Groius: Annual Lecture on A Mastermind. London: Humphrey Milford, 2005.

Levering, Mathew. Biblical Natural Law: A Theocentric and Teleological Approach. London: Oxford University Press, 2008. DOI: 10.1017/ CBO9781107415324.004.

Lutfi, Khoirur Rizal. "Teori Hukum Alam dan Kepatuhan Negara terhadap Hukum Internasional”. Jurnal Yuridis, 1, 1 (2014): 91-106. McLeod, Ian. Legal Theory, diedit oleh Marise Cremona. London: MacMillan Press, 1999. DOI: 10.1007/978-1-349-142696-9.

Miller, John. "Hugo Grotius", Stanford Encyclopedia of Philosophy, Stanford University, 2014. Https:/ / plato.stanford.edu/entries/ grotius/. Diakses 10/10/2019.

Novak, David. "Natural Law and Judaism". Dalam Natural Law: A Jewish, Christian and Muslim Trialogue, diedit oleh Anver M Emon, Matthew Levering, dan David Novak, 4-67. Oxford: Oxford University Press, 2014.

Onuma, Yasuaki. Introduction to Normative Approach to War: Peace, War, and Justice in Hugo Grotius. Oxford: Clarendon Press, 1993.

Patterson, Dennis. A Companion to Philosophy of Law and Legal Theory: A Companion to Philosophy of Law and Legal Theory. Oxford and Cambridge: Blackwell, edisi kedua, 1996. DOI: $10.1002 / 9781444320114$.

Samekto, F.X. Adji. "Menggugat Relasi Filsafat Positivisme dengan Ajaran Hukum Doktrinal”. Jurnal Dinamika Hukum, 12, 1 (2012): 74-84. 
Shaver, Robert. "Grotius on Scepticism and Self-Interest". Dalam Grotius, Purfendorf and Modern Natural Law, diedit oleh Tom Campbell, 63-84. Brookfield: Ashgate Publishing Company, 1999.

Steenbrink, Karel. Kaum Kolonial Belanda dan Islam di Indonesia (15961942). Terjemah oleh Suryan A. Jamrah. Yogyakarta: Gading, 2017.

Straumann, Benjamin. "Ancient Caesarian Lawyers in a State of Nature: Roman Tradition and Natural Rights in Hugo Grotius's De Iure Praedae”. Political Theory, 34, 3 (2006): 328-50. DOI: $10.1177 / 0090591706286459$.

Teson, Fernando R. Liberty Matters: Hugo Grotius on War and the State. Indianapolis: Liberty Fund, 2014.

Thomasius, Christian, Ian Hunter, Thomas Ahnert, dan Frank Grunert. Essays on Church, State, and Politics, diedit oleh Haakonssen. Indianapolis: Liberty Fund, 2007.

Thontowi, Jawahir. "Pengembangan Ilmu Hukum Berbasis Religiuos Science: Dekonstruksi Filsosofis Pemikiran Hukum Positivistik". Pandecta: Research Law Journal, 6, 2 (2013): 201-14. DOI: 10.15294 / pandecta.v6i2.2338.

Tuck, Richard. "Introduction". Dalam The Rights of War and Peace Book I, diedit oleh Richard Tuck, ix-xxxviii. Indianapolis: Liberty Fund, 2012. DOI: $10.2307 / 2642066$.

Wall, Ernestine van der. "Between Grotius and Cocceius: The 'Theologia Prophetica' of Campegius Vitringa (1659-1722)”. Dalam Hugo Grotius, Theologian: Essays in Honour of G.H.M. Posthumus Meyjes, diedit oleh Henk J.M. Nellen and Edwin Rabbie, 195-215. Leiden: Brill, 1994.

Westerman, Pauline C. The Disintegration of Natural Law Theory: Aquinas to Finnis, diedit oleh A.J. Vanderjagt, dkk. Leiden: Brill, 1998.

White, Robert Sommerville. Natural Law in English Renaissance Literature. Cambridge: Cambridge University Press, 2006.

Wilson, Eric. "The Dangerous Classes: Hugo Grotius and SeventeenthCentury Piracy as A Primitive Anti-Systemic Movement”. Journal 
Aulia Rahmat

of Philosophical Economics, 4, 1 (2010): 146-83.

Wolfe, Chripstopher. Natural Law Liberalism. Cambridge: Cambridge University Press, 2006. 